\title{
DIVORCE IN SOUTH AFRICA: AN OVERVIEW
}

\section{Ackerman}

\author{
University of the Free State
}

\begin{abstract}
This article provides an overview of South African divorce figures given for the past five years. The various ways in which divorce figures can be expressed are considered, with specific reference to South Africa. When studying the crude divorce rate, two things become apparent. Firstly, the South African crude divorce rate is relatively low when compared to various other countries (contrary to the popular belief that South Africa has one of the highest divorce rates in the world) and, secondly, the South African divorce rate is rising and will probably continue to rise. In conclusion, it is argued that various macro social forces are likely to increase the number of divorces in the near future.
\end{abstract}

\section{INTRODUCTION}

Divorce as a societal phenomenon is of interest to most fields in the social sciences, particularly to social work, psychology and sociology. This paper focuses on the various ways in which divorce figures can be reported, with specific reference to South African data. In addition, brief sociological insights into the macro reasons for divorce in South Africa are also presented.

\section{COLLECTING DATA}

In most countries divorce statistics are recorded at a central point. In South Africa this information is recorded at Statistics South Africa ${ }^{1}$. The data in this article that pertain to South Africa were gleaned mainly from this source. Statistics South Africa, through the registrars of the twelve Supreme Courts, administers the divorce form, and data capture and editing are all carried out at Statistics South Africa.

It is important to remember that information up to 1999 only included marriages and divorces recorded by the civil registration system and excluded marriages solemnised under customary and certain religious rites ${ }^{2}$. Nevertheless, with the available information, certain trends can be discerned and, once the new information is available, it can be compared to older statistics to see what impact the inclusion of customary marriages has on statistics.

In addition, all pre-1994 statistics excluded Black people and thus were not a true representation of the South African population as a whole (for this reason most tables in this article start from 1994).

1 Known as the Central Statistical Service prior to 1999.

2 The vital registration system now recognises and records those marriages solemnised under customary rites - enactment of the Recognition of Customary Marriages Act of 120 of 1998. These new figures have been included from the year 2000 (Statistics South Africa, 1999). 


\section{CLARIFYING CONCEPTS - APPLICATION TO SOUTH AFRICAN DATA}

There are basically five ways of reporting divorce statistics. Any social scientist working with divorce statistics should take note of the various ways in which this information can be expressed and what each expression entails.

\section{Absolute number of divorces}

In this instance the actual number of divorces is counted for a certain area for a certain time period (usually a year). The actual number of divorces does not reveal information about the actual risk of divorce, because it does not consider the population base. The absolute number might go up simply because there are more persons in a population (Starbuck, 2002:404).

TABLE 1

ABSOLUTE NUMBER OF DIVORCES IN SOUTH AFRICA PER POPULATION GROUP (1990-1999)

\begin{tabular}{llllllll}
\hline & Total & Asian & White & Coloured & Black & Mixed & Unspecified \\
\hline 1990 & $\mathbf{2 6 ~ 6 6 9}$ & 1421 & 20031 & 5217 & - & & \\
\hline 1991 & $\mathbf{2 3 ~ 8 6 5}$ & 1410 & 17398 & 5057 & - & & \\
\hline 1992 & $\mathbf{2 8 ~ 2 6 4}$ & 1850 & 21006 & 5408 & - & & \\
\hline 1993 & $\mathbf{2 6 ~ 6 1 6}$ & 1676 & 19020 & 5920 & - & & \\
\hline 1994 & $\mathbf{2 9 ~ 8 7 8}$ & 1684 & 18250 & 5190 & 4754 & & \\
\hline 1995 & $\mathbf{3 1 ~ 5 9 2}$ & 1601 & 16788 & 5029 & 8174 & & \\
\hline 1996 & $\mathbf{3 2 ~ 7 7 5}$ & 1489 & 15831 & 4190 & 7243 & 191 & 3831 \\
\hline 1997 & $\mathbf{3 4 2 3 1}$ & 1685 & 15295 & 4634 & 7174 & 184 & 5259 \\
\hline 1998 & $\mathbf{3 5 7 9 2}$ & 1753 & 14443 & 3790 & 6673 & 250 & 8883 \\
\hline 1999 & $\mathbf{3 7 ~ 0 9 8}$ & 1976 & 14785 & 3938 & 6823 & 357 & 9219 \\
\hline
\end{tabular}

[Compiled from: Statistics South Africa, 1999; Statistics South Africa, 2000b; Statistics South Africa, 2002b]

The absolute number of divorces in South Africa has shown a steady increase, with 1999 (latest available figure) showing the highest number of 37 098. Admittedly these numbers may increase yearly because the actual number of people in South Africa increases yearly. This figure can, however, give one an indication of the actual number of individuals and children affected by divorce who may need help.

\section{Divorce-to-marriage ratio}

The second way of expressing divorce figures is by taking the number of divorces and dividing this number by the number of marriages that took place in a given year - this gives a divorce-tomarriage ratio. Starbuck (2002:404) points out that "Many people read these figures [divorce-tomarriage ratio] as saying if the figure is .50 they interpret it as $50 \%$ of all marriages will end in divorce. This is not necessarily the case, because the divorces in any given year are from marriages from many previous years and are being compared to the marriages from only one year." Gelles (1995:390) states that: "Of all the possible ways of measuring the risk of divorce, this one seems to be the most widely reported in the media and the most inaccurate and least valid!" 
TABLE 2

SOUTH AFRICAN DIVORCE-TO-MARRIAGE RATIO (1992-1999)

\begin{tabular}{ccc}
\hline Year & Divorces/marriages & Ratio \\
\hline 1992 & $28264 / 111557$ & $\mathbf{0 . 2 5 3}$ \\
\hline 1993 & $26616 / 120159$ & $\mathbf{0 . 2 2 2}$ \\
\hline 1994 & $29878 / 133309$ & $\mathbf{0 . 2 2 4}$ \\
\hline 1995 & $31592 / 148148$ & $\mathbf{0 . 2 1 3}$ \\
\hline 1996 & $32775 / 146732$ & $\mathbf{0 . 2 2 3}$ \\
\hline 1997 & $34231 / 146729$ & $\mathbf{0 . 2 3 3}$ \\
\hline 1998 & $35729 / 146741$ & $\mathbf{0 . 2 4 3}$ \\
\hline 1999 & $37098 / 155807$ & $\mathbf{0 . 2 3 8}$
\end{tabular}

[Compiled from: Central Statistical Service, 1995; South African Institute of Race Relations, 1998; Statistics South Africa, 1999; Statistics South Africa, 2000a; Statistics South Africa, 2000b; Statistics South Africa, 2002b]

In 1999, 37098 South Africans got divorced and 155807 got married. Thus 37098 divided by 155807 gives a figure of 0.238 . This, however, must not be interpreted as indicating that $23,8 \%$ of all marriages will end in divorce.

\section{The crude divorce rate}

This is one of the most common ways of reporting divorce figures. The crude divorce rate can be defined as the number of divorces per 1000 persons in the population (Davidson \& Moore, 1992:460). This rate is obtained by dividing the number of divorces by the number of people in a population and then multiplying by 1000 . Some sources (such as Statistics South Africa) express this figure per 100000 of a population (Statistics South Africa, 2002:6). Whether per 1000 or 100000 (of a population), it is important for a researcher to be able to convert the figure to a comparable figure. Thus if a figure of 83.4 per 100000 is given, it should be converted to 0.834 per 1000 when comparing with other countries.

TABLE 3

THE CRUDE DIVORCE RATE OF THE SOUTH AFRICAN POPULATION (1994-1999)

\begin{tabular}{cccc}
\hline & Divorces & $\begin{array}{c}\text { Population (mid-year } \\
\text { estimates) }\end{array}$ & Crude rate per 1000 \\
\hline 1994 & 29878 & 38630500 & $\mathbf{0 . 7 7 3 4}$ \\
\hline 1995 & 31592 & 39477100 & $\mathbf{0 . 8 0 0 2}$ \\
\hline 1996 & 32775 & 40342300 & $\mathbf{0 . 8 1 2 4}$ \\
\hline 1997 & 34231 & 41226700 & $\mathbf{0 . 8 3 0 3}$ \\
\hline 1998 & 35792 & 42130500 & $\mathbf{0 . 8 4 9 5}$ \\
\hline 1999 & 37098 & 43054300 & $\mathbf{0 . 8 6 1 6}$ \\
\hline
\end{tabular}

[Compiled from: Statistics South Africa, 1999; Statistics South Africa, 2000b; Statistics South Africa, 2002b; South African Institute of Race Relations, 2000]

In 1999 there were 37098 divorces in South Africa, divided by a total South African population of 43054300 and multiplied by 1000 gives a rate of 0.8616 . The crude rate increased progressively 
in the 1994-1999 year period. Due to macro societal factors (which will be dealt with later in this article), this rate will probably continue to rise.

When the South African divorce rate is compared to that of several other countries, it becomes clear that South Africa's crude rate is not that high (see Figure 1). From the available evidence, countries such as Cuba and the USA have much higher rates (rates of about 4.00 per 1000). What is interesting to note is that most countries appear to rise, peak and stabilise. The USA, for example, peaked in the early 1980s with a divorce rate of 5.2 and has stabilised at about 4.7 per 1000 (Davidson \& Moore, 1992:460). It remains to be seen if South Africa will follow a similar pattern.

\section{FIGURE 1}

\section{CRUDE DIVORCE RATES OF SELECTED COUNTRIES (1994-1999)}

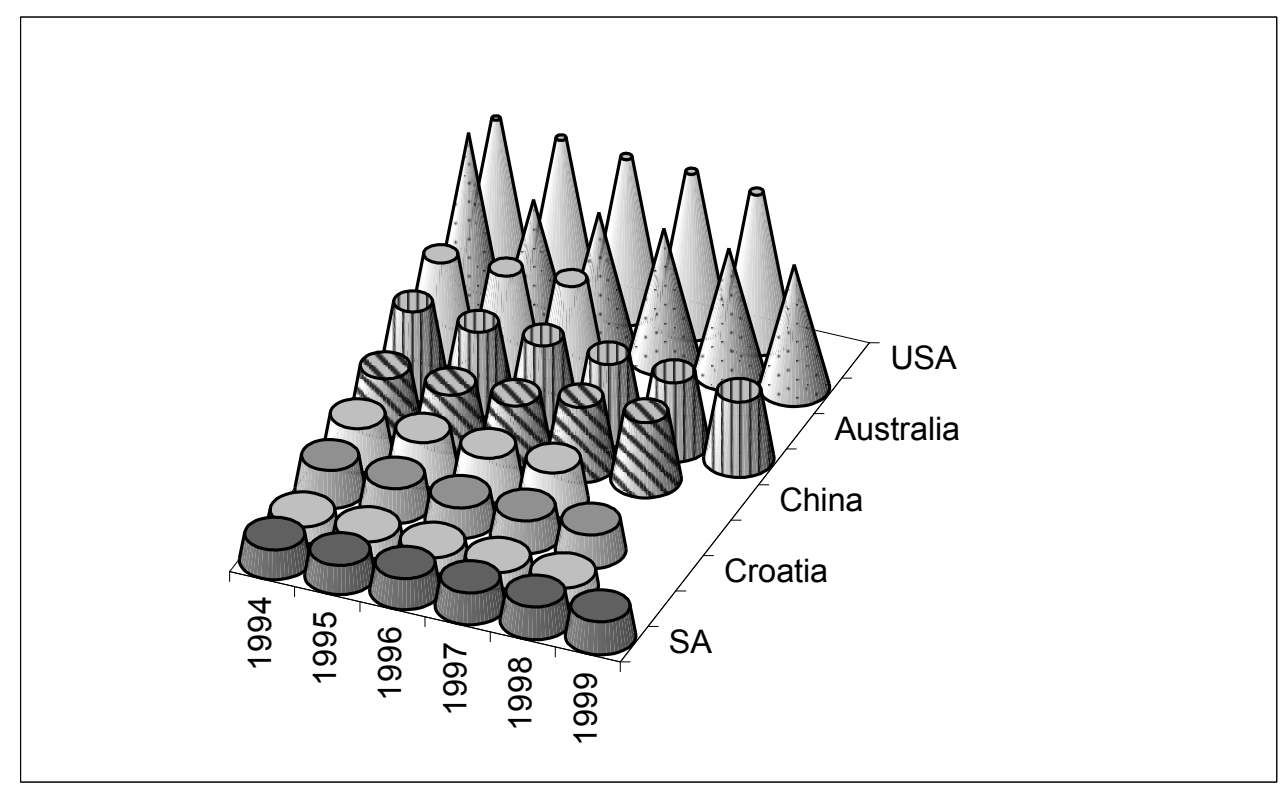

[Compiled from: United Nations, 2001; United Nations, 1999]

Note: When no cones are present, it does not signify a rate of 0 ; it means that no information is available.

Popular opinion has it that South Africa has one of the highest divorce rates in the world. This misconception is probably due to the fact that Whites, as a group, had a crude divorce rate of about 4 per 1000 in the early 1990s (Statistics South Africa, 1999:4). However, when the country is taken as a whole, it is clear that South Africa is not a world leader in terms of the crude divorce rate.

It must be borne in mind, when considering the crude divorce rate, that not all persons in a population are married. The population (used in the formula) includes infants and single adults who are not at risk of divorce (because they are not married!). Thus, this rate underestimates the yearly risk of divorce of a married person. However, despite this shortcoming, this is the most 
common way of expressing the divorce rate and is found in most demographic yearbooks and is a useful tool when comparing various countries with one another.

\section{Refined divorce rate}

Another, more precise, way of expressing divorce figures is the refined divorce rate (also termed the modified crude divorce rate). The refined divorce rate is the number of divorces per 1000 married couples in a society. There are various ways of determining how many married couples there are in a society (usually the number of married women is used as the denominator). The refined rate is a more accurate figure as only those at risk of divorce are included in the formula. However, despite the refined rate being a better way of expressing the divorce rate, most international figures are expressed as a crude divorce rate.

TABLE 4

THE REFINED DIVORCE RATE FOR SOUTH AFRICA (1994-1999)

\begin{tabular}{cccc}
\hline & Divorces & Married couples* & Refined rate per 1000 married couples \\
\hline 1994 & 29878 & 38630500 & $\mathbf{5 . 8 9 6 6}$ \\
\hline 1995 & 31592 & 39447100 & $\mathbf{6 . 1 0 1 1}$ \\
\hline 1996 & 32775 & 40342300 & $\mathbf{6 . 1 5 7 0}$ \\
\hline 1997 & 34231 & 41226700 & $\mathbf{6 . 3 3 0 3}$ \\
\hline 1998 & 35792 & 42130500 & $\mathbf{6 . 4 7 7 0}$ \\
\hline 1999 & 37098 & 43054300 & $\mathbf{6 . 6 0 4}$ \\
\hline
\end{tabular}

[Compiled from: Statistics South Africa, 1999; Statistics South Africa, 2000b; Statistics South Africa, 2002b (with the help of Dr S Bah)]

* It is difficult to obtain an accurate figure of married couples in the years between censuses. This table reflects Statistics South Africa's calculations. The number of married couples was obtained for the 1996 census and then the proportion of married couples for the population was worked out. This proportion was then applied to the mid-year estimates of the years between censuses to calculate the number of married couples.

The refined rate of 1999 is higher than the crude rate of the same year (6.604 and 0.8616 respectively). The refined rate, like the crude rate, has increased steadily over recent years, revealing that a greater proportion of married people are getting divorced.

\section{Average marriage risk and marital dissolution and survivorship}

The most accurate way of determining what percentage of marriages will end in divorce would be to determine the average marital risk. "This would be some figure that would indicate what percentage of marriages that begin in a given year would eventually end in divorce... To calculate this rate correctly would require a longitudinal study. All marriages registered in 1996, for example, would be followed until they ended in divorce or death. After all marriages had ended, the percentage ending in divorce could be calculated. This would take at least until $2076 \ldots$ or one could go back to 1916 and see how many marriages of that year ended in divorce. However, since the divorce rate has gone up since then, that figure would not be very useful for predicting the stability of today's marriages" (Starbuck, 2002:405). Gelles (1995:392) claims that it is unlikely that any researcher would undertake this time-consuming and expensive study - the results of which would be dated by the time they were available! 
Another way of gaining an insight into the chances of a marriage ending in divorce is calculating the figures that relate to marital dissolution and survivorship. This involves looking at marriages that started in a certain year and then assessing how many of those marriages had ended in divorce at the time of study. Thus, for example, one could look at marriages that started in 1993 and then establish how many of these marriages had ended in divorce by the year 2003. Statistics South Africa reported this information up until 1994, but unfortunately since this date such information is no longer included in the "Marriage and Divorce" reports. For example, 30,45\% of all White marriages that were solemnised in 1973 were dissolved by divorce by 1993 and 13,57\% of marriages that were solemnised in 1990 had already ended in divorce three years later (Central Statistical Service, 1995:91).

Considering all the above, it is clear that the actual number of divorces is increasing as well as the divorce rate itself (crude and refined).

\section{MACRO REASONS FOR DIVORCE}

When explaining divorce rates, most sociologists divide the reasons for divorce into: macro-level reasons; demographic variables and interpersonal reasons (Benokraitis, 1996; Gelles, 1995; Starbuck, 2002). This article will focus only on possible macro reasons for divorce.

When approaching divorce from a macro level one looks at changes in the broader society that:

- may cause people to be more unhappy in their particular marriage (here one looks broader influences that have an effect on expectations within a marriage and definitions of what constitutes a good marriage);

- $\quad$ may make it easier for people to escape an unhappy marriage (a higher divorce rate could thus in fact point to increased mechanisms to escape an unhappy marriage). It is important to keep in mind that a low divorce rate does not necessarily mean that marriages are happier, but rather that individuals do not have ways of getting out of an unhappy marriage.

\section{Legal institutions}

When considering the legal institutions, laws prohibiting or making divorces easier have an effect on the divorce rate. Many sociologists argue that the "no fault" divorce laws of the 1970s had a tremendous effect on the number of people who divorced in the USA. Divorces became "...more an administrative matter than an issue battled out in the courts" (Starbuck, 2002:406). Prior to the divorce reforms, one spouse had to be guilty of some or other misbehaviour (such as adultery, alcoholism, insanity, etc.), which made it more difficult for people to obtain a divorce. In South Africa the no-fault divorce $\mathrm{Act}^{3}$ came into effect on 1 July 1979 (Barnard, 1983:39). In the years following the new act there was a sharp increase in the number of divorces in South Africa (Burman \& Huvers, 1985:125).

In South Africa another two recent laws pertain to the divorce issue. The first is the Divorce Courts Amendment Act of 1997, which came into effect in April 1998. This law made it possible for people of all races to apply for divorce in either the High Court or the Central Divorce Court. Obtaining a divorce in the Central Divorce Court is less costly because litigants do not require legal representation - this option, prior to April 1998, was open only to Africans, but now - as stated before - is open to all races (South African Institute of Race Relations, 1998:4). This in itself could lead to more divorces as they are easier and cheaper to obtain. The second law is the 
"Recognition of Customary Marriages Act" of 1998. This act provides for the recognition and regulation of customary marriages (marriages concluded in accordance with customary law). The act also recognises polygamy in customary marriages. This law will thus have a direct influence on the number of marriages recorded and therefore ultimately divorce statistics.

Moreover, customary marriages (after commencement of the act) would be in community of property, unless an antenuptial contract was signed; previously a women did not have any recourse in the event of divorce unless her husband voluntarily gave her some of the assets (South African Institute of Race Relations, 1999:4). Thus women in customary marriages may be more likely to opt for a divorce as they have some form of legal protection, something they did not have in the past.

\section{Religious institutions}

Social institutions are the accepted patterns of behaviour and ultimately shape the behaviour of members in society. The strongest argument against divorce came from various religions, prohibiting divorce. However, there has been changes in the way that religious organisations view divorce and treat those who have been divorced. Many Christian denominations do not object to a person marrying someone who has previously been divorced and also do not ostracise a member who has divorced. In addition, the divorce and remarriage of high-profile ministers all point to an increased acceptance of divorce within certain religious spheres. Changes within the religious institution have an effect on the decisions that members of a society make. If religious institutions no longer negatively sanction divorce as they did in the past, divorce becomes an option to be considered by individual.

\section{Changing gender roles and the entry of women into the labour market}

In this instance an increase in the power of women in society in general and in marital relationships in particular becomes relevant. With the democratisation of South Africa the idea of equality and non-discrimination enjoys prominence. Values of gender equality are entrenched in the law and, although gender discrimination has not been eliminated, it is unacceptable in the eyes of the law and increasingly so in the eyes of members of society.

Coupled to this ideological change regarding equality between men and women is the entry of women into the labour force. Women have increasingly become part of the labour force in South Africa, as Table 5 indicates.

TABLE 5

PERCENTAGE OF SOUTH AFRICAN LABOUR FORCE THAT CONSISTS OF WOMEN FOR SELECTED YEARS

\begin{tabular}{cc}
\hline Year & Percentage of workforce consisting of women \\
\hline 1960 & $\mathbf{2 3 \%}$ \\
\hline 1985 & $\mathbf{3 6 \%}$ \\
\hline 1991 & $\mathbf{4 1 \%}$ \\
\hline 1994 & $\mathbf{4 4 \%}$ \\
\hline 1996 & $\mathbf{4 8 \%}$ \\
\hline
\end{tabular}

[Source: De Jong, 1999:78; Popenoe, Cunningham \& Boult, 1998:259]

The ideological changes as well as the entry of women into the labour force have the effect of heightening the power of women in interpersonal relationships. Many sociologists (Benokraitis, 
1996:458; Davidson \& Moore, 1992:464; Gelles, 1995:394-395) argue that this situation can increase the likelihood of divorce because as far as women are concerned:

- $\quad$ women are becoming more assertive regarding their needs (physical and emotional);

- $\quad$ new gender role expectations are starting to arise. For example, women expect men to help them with domestic tasks, something that has traditionally not been considered a man's role;

- women may experience increased unhappiness if new expectations are not met;

- $\quad$ if women are employed, they are more likely to leave a relationship if the above needs are not met, because they are able to support themselves;

- $\quad$ women are more likely to divorce their husbands if the latter are unfaithful, as they are more able to support themselves;

- $\quad$ women may experience work stress and fatigue, which places more stress on the marriage.

On the other hand, the liberation of women also has an effect on the way that men view marriage and thus also contributes to an increased divorce rate because:

- men may feel less guilty about leaving their wives, as they believe that working wives can care for themselves;

- men may feel threatened if their wives earn more than what they do;

- men may be unwilling to assist in household tasks they believe (or have been socialised to believe) are not part of their role description (conflicting expectations regarding roles);

- increasing opportunities to get custody of their children may encourage men to leave unhappy marriages as in the past they had very little chance of getting custody of their children and for their children's sake remained in an unhappy marriage.

Looking at South Africa, women are indeed entering the labour force in greater numbers (Table 5) and are making up a large proportion of the work force and changes regarding role expectations are taking place. Seeing that much of the research shows that changing gender roles, especially women's growing presence in the labour force, are associated with an increase in divorce rates (Benokraitis, 1996:458), it is likely that this factor will contribute considerably to an increase in the South African divorce rate.

\section{Cultural values}

Although cultural values is a broad topic, one value that pertains to the divorce issue will be touched on in this section. With an increase in the ideas of individual self-actualisation and selffulfilment, divorce is becoming more accepted and not considered as deviant as it was in the past. In this regard Goode (1982:155) states that there is: “...one change in values has affected choices in most of the modern world. This is the belief that people have a right to make decisions on the basis of what they believe will bring them happiness, or satisfy their self-defined needs. This is given the negative label of 'hedonism' in some discussions, and the positive label of 'selffulfilment' in others."

The result is that divorce in no longer considered a scandal. Where traditionally marriage was seen as a sacred institution, the foundation of a good society (Gelles, 1995:395) and as an "indissoluble bond" (De Jong, 1999:76), this is no longer the case. If behaviour is no longer negatively sanctioned by the majority of people in society, it makes it easier to engage in. The interaction 
between a decrease in negative perceptions regarding divorce and an increase in the more secular view that you live life once and that life is too short to be wasted in an unhappy marriage has the effect of increasing the divorce rate.

\section{CONCLUDING COMMENTS}

Reviewing the statistics, it is evident that the South African divorce rate (crude rate) is not high when compared to that of other countries, but all indications are that it is rising steadily and will probably continue to rise for some time. This can be due to various macro social forces in the country that contribute to an increased divorce rate. It remains to be seen if the South African divorce rate will peak, at what level this will happen and whether or not the different groups in South Africa will eventually manifest similar rates.

However, despite the increase in divorce rate, marriage as an institution has not been rejected as people continue to marry and remarry after divorce. In $199821,5 \%{ }^{4}$ of people entering marriage (in that year) had previously been divorced - thus divorce does not necessarily signal dissatisfaction with marriage in general, but rather with a specific marriage.

\section{Acknowledgements}

Dr S Bah is acknowledged for his help regarding the calculation of the refined divorce rate.

\section{REFERENCES}

BARNARD, A.H. 1983. An evaluation of the divorce act 70 of 1979. Acta Juridica, 39-51.

BENOKRAITIS, N.V. 1996. Marriages and families: Changes choices and constraints $\left(2^{\text {nd }} \mathrm{ed}\right)$. London: Prentice Hall.

BURMAN, S. \& HUVERS, M. 1985. Church versus State? Divorce legislation and divided South Africa. Journal of Southern African Studies, 12(1):116-135.

CENTRAL STATISTICAL SERVICE, 1994. South African Statistics 1994. Pretoria.

CENTRAL STATISTICAL SERVICE, 1995. Marriages and Divorces, 1993 (CSS report No. 03-07-01). Pretoria: Central Statistical Service.

CENTRAL STATISTICAL SERVICE, 1996. Marriages and Divorces, 1994 (CSS report No 03-07-01). Pretoria: Central Statistical Services.

CENTRAL STATISTICAL SERVICE, 1998. Marriages and Divorces, 1995 (CSS report No. 03-07-01). Pretoria: Central Statistical Service.

DAVIDSON, J.K. \& MOORE, N.B. 1992. Marriage and family. Dubuque (Iowa) USA: Wim C. Brown Publishers.

DE JONG, M. 1999. New trends regarding the maintenance of spouses upon divorce. Tydskrif vir Hedendaagse Romeins Hollandse Reg, 62(1):75-87.

GELLES, R.J.1995 Contemporary families: a sociological view. California: Sage.

GOODE, W.J. 1982. The family ( $2^{\text {nd }}$ ed). Englewood Cliffs New Jersey: Prentice Hall.

POPENOE, D.; CUNNINGHAM, P. \& BOULT, B. 1998. Sociology: First South African Edition. South Africa: Prentice Hall.

SOUTH AFRICAN INSTITUTE OF RACE RELATIONS, 1998. South Africa Survey 1997/98. Johannesburg: South African Institute of Race Relations. 
SOUTH AFRICAN INSTITUTE OF RACE RELATIONS, 2000. South Africa Survey 1999/2000 (Millenium edition): Johannesburg: South African Institute of Race Relations.

STARBUCK, G.H. 2002. Families in context. South Melbourne Australia: Wadsworth.

STATISTICS SOUTH AFRICA, 1999. Marriages and Divorces, 1996 (Report No. 03-07-01). Pretoria: Statistics South Africa.

STATISTICS SOUTH AFRICA, 2000a. South African Statistics 2000. Pretoria: Statistics South Africa.

STATISTICS SOUTH AFRICA, 2000b. Marriages and Divorces, 1997 and 1998 (Statistical release P0307). Pretoria: Statistics South Africa.

STATISTICS SOUTH AFRICA, 2002a. South African Statistics 2001. Pretoria: Statistics South Africa.

STATISTICS SOUTH AFRICA, 2002b. Marriages and Divorces, 1999 (Statistical release P0307). Pretoria: Statistics South Africa.

STEINMETZ, S.K.; CLAVAN, S. \& STEIN, K.F. 1990. Marriage and family realities: Historical and contemporary perspectives. New York: Harper \& Row.

UNITED NATIONS, 1999. Demographic Yearbook 1997 (Forty-ninth issue). Geneva: United Nations.

UNITED NATIONS, 2001. Demographic Yearbook 1999 (Fifty-first issue). Geneva: United Nations.

Ms L Ackermann, Lecturer at the Department of Sociology, Faculty of Humanities, University of the Free State, Bloemfontein, South Africa. 